\title{
VIEWPOINTS
}

\section{Rukun Negara as The Preamble to The Federal Constitution}

\author{
Mohamed Azam Mohamed Adil *
}

The call by some groups to incorporate the Rukun Negara as the preamble to the Federal Constitution is timely. The Rukun Negara was first introduced as the national philosophy by the fourth Yang di-Pertuan Agong, the late Sultan of Terengganu, during Merdeka Day in 1970.

Among the primary goals of the Rukun Negara are to realise Malaysia's ambitions towards enhancing unity among the people; safeguarding the spirit of democracy; establishing a just society; maintaining a liberal approach in addressing diversity; and creating a progressive and technologically advanced society.

In fulfilling the above ideals, the Rukun Negara underlines five core principles: Belief in God; Loyalty to King and Country; Supremacy of the Constitution; Rule of Law; and Good Behaviour and Morality. Today, the Rukun Negara has become more relevant than ever in three ways:

FIRST, the philosophy of unity embedded within the Rukun Negara is essential to cultivate ethnic harmony, which has been continually tested throughout the country's history. Many point towards the Malayan Union controversy in 1946 as the turning point that marked the heightening of ethnic consciousness and nationalism among the various ethnic groups in the Malay Peninsula.

The Malays, across all strata of society, opposed the Malayan Union while the non-Malays were more ambivalent. This was likely due to the Malayan Union's direct implication for Malay interests such as restriction on the powers of the sultans, reduction of Malay special privileges and loosening of citizenship requirements. The Malayan Union was then superseded by the Federation of Malaya in 1948.

Voices demanding independence grew stronger and the British were compelled to concede, but not before imposing several prerequisites. Among the conditions for independence was that all ethnic groups demonstrate their ability to cooperate and live together. The success of the Perikatan coalition which consisted of multiethnic parties had proven the close ties and tolerance among the races under the 
spirit of "give and take". Consequently, Malaya gained independence on Aug 31, 1957.

Ethnic unity was again tested during the formation of Malaysia in 1963. The entry of Singapore, Sabah and Sarawak provided a significant demographic shift. Singapore introduced a bigger share of Chinese populace while Sabah and Sarawak introduced a wide variety of ethnic groups and tribes. For Sabah and Sarawak, the 20-point agreement has been laid down and added to the Federal Constitution to preserve ethnic identities and state rights. The inclusion of the Rukun Negara as the preamble would be a great addition to our multicultural Constitution.

SECOND, in terms of economic disparity, the Rukun Negara's philosophy of a just society is an essential guiding principle. The far-reaching economic gap between the indigenous and non-indigenous populations continues to be a significant concern. Prolonged economic inequality is known to breed prejudice and disunity within society. The Rukun Negara itself was drafted in response to the infamous May 13, 1969 racial riots. This incident witnessed the suspension of the Constitution and the formation of the National Operations Council (MAGERAN) as the caretaker government to restore order and peace. In addition to the Rukun Negara, the New Economic Policy was also introduced to reduce economic disparity and ensure a fairer and more equitable distribution of the nation's wealth.

THIRD, the Rukun Negara as a preamble would significantly assist in interpreting the Federal Constitution. In this matter, the Rukun Negara can serve in three dimensions: providing the overarching ideals of unity, serving as the guiding principle in interpreting constitutional provisions and providing a substantive confirmation to the law.

In this regard, the author wishes to emphasise the first dimension based on the crucial need to cultivate national unity, especially considering the current social reality and the many voices raised against it.

However, some parties question the need to incorporate the Rukun Negara as the preamble after 61 years of independence, and how it might impact the Constitution. In response, the author argues that inserting the Rukun Negara into the Federal Constitution will not diminish or limit any provision in the Constitution itself. This is because all the provisions contained in the Constitution are inter-related and mutually binding. The provisions cannot be read in isolation and without comprehensively viewing the document.

Key provisions in the Constitution remain intact and safeguarded. These include Article 3 (1) which establishes Islam as the religion of the Federation, Article 153 on the special position of the Malays and the Bumiputeras of Sabah 
and Sarawak, Article 152 on the Malay language, and Article 38 on the rights and privileges of the Malay Rulers and Council of Rulers.

Constitutional preambles generally emphasise general values and will not interfere with the essence and indigenous elements of the Constitution itself. Further discussion on the incorporation of Rukun Negara as the preamble to the Constitution is essential so that all parties understand its purpose and benefits. Meantime, one should not dismiss this proposal merely on the grounds that the Reid Commission that drafted the Federal Constitution did not include the preamble.

Likewise, provisions in the Federal Constitution are always flexible and may be amended in accordance with the will of the people. They may be amended by members of parliament taking into consideration the benefits for a multiracial and multireligious nation.

\section{Notes}

* Mohamed Azam Mohamed Adil is Deputy CEO, International Institute of Advanced Islamic Studies (IAIS) Malaysia, Jalan Elmu off Jalan Universiti, 59100 Kuala Lumpur/Associate Professor, Academy of Contemporary Islamic Studies (ACIS), Universiti Teknologi MARA Selangor, 40450 Shah Alam, Selangor (mazamadil@iais.org.my/mazamadil1966@hotmail.com). 